\title{
Relationship between soil organic matter and nematodes in sugarcane fields
}

\section{Relações entre a matéria orgânica e os nematoides em área cultivada com cana-de-açúcar}

\author{
Patrícia Ângelo de Barros ${ }^{1}$; Elvira Maria Régis Pedrosa ${ }^{2 *}$; \\ Mércia Soares de Oliveira Cardoso ${ }^{3}$; Mario Monteiro Rolim ${ }^{4}$
}

\begin{abstract}
Sugarcane plays an important socio-economic role in northeastern Brazil. However, the low yield in this region is associated with several factors (e.g. frequent occurrence of plant-parasitic nematodes). In order to observe the influence of soil organic matter on the nematodes, this study aimed to characterize the spatial nematode distribution in a sugarcane field. The study was carried out in Goiana - Pernambuco State (Brazil), fifty days after sugarcane cutting (10 days after vinasse application). The sampling scheme consisted of a regular $60 \times 50$-m grid, $10 \mathrm{~m}$ spaced, through 0 to $0.2 \mathrm{~m}$ depth. Spatial distribution was evaluated by semivariograms fit and performed by ordinary kriging interpolation for mapping. Exponential and spherical models promoted the best fit to semivariograms, resulting in ranges from 16 to $19 \mathrm{~m}$. There was a strong negative correlation between soil organic matter and plantparasitic nematode population density. Free-living nematodes had a similar distribution pattern as soil organic matter content. These results indicated that soil organic matter had important effects on spatial distribution of both plant-parasitic and free-living nematodes.
\end{abstract}

Key words: Soil microfauna. Semivariogram. Spatial variability. Vinasse.

\section{Resumo}

A cana-de-açúcar desempenha importante papel socioeconômico para o Nordeste Brasileiro. Por outro lado, a baixa produtividade nesta região está associada a diversos fatores, dentre estes, a relevante presença de nematoides fitoparasitas. A fim de verificar a influência da matéria orgânica sobre os nematoides, o objetivo deste estudo foi caracterizar a distribuição espacial da matéria orgânica e da nematofauna em área cultivada com cana-de-açúcar fertirrigada com vinhaça. $\mathrm{O}$ estudo foi realizado no município de Goiana, Zona da Mata Norte de Pernambuco, 50 dias após corte da cana (10 dias após aplicação da vinhaça). Utilizou-se um sistema de amostragem em malha regular de $60 \times 50 \mathrm{~m}$, com espaçamento de $10 \mathrm{~m}$, na profundidade de 0-0,2 m. A distribuição espacial foi avaliada por meio de ajustes de semivariogramas e realizada interpolação por krigagem ordinária para mapeamento. $\mathrm{O}$ modelo esférico e o exponencial proporcionaram melhor ajuste aos semivariogramas, com alcances de 16 a 19 m. A matéria orgânica correlacionou-se negativamente com a população dos nematoides fitoparasitas. O mapeamento permitiu observar padrões de distribuição espacial similares entre as comunidades de nematoides de vida livre e a matéria orgânica. Esses resultados indicam que a matéria orgânica tem um papel importante na distribuição espacial dos nematoides fitoparasitas e de vida livre. Palavras-chave: Microfauna do solo. Semivariograma. Variabilidade espacial. Vinhaça.

\footnotetext{
${ }^{1}$ Graduate student, Programa de Pós-Graduação em Engenharia Agrícola, PGEA, Universidade Federal Rural de Pernambuco, UFRPE, Recife, PE, Brasil. E-mail: paty.angell@hotmail.com

2 Prof ${ }^{a}$ PhD., Departamento de Engenharia Agrícola, UFRPE, Recife, PE, Brasil. E-mail: elvira.pedrosa@ufrpe.br

3 Post-doctoral researcher, PGEA, UFRPE, Recife, PE, Brasil. E-mail: mercia.cardoso@yahoo.com.br

${ }^{4}$ Prof. Dr., Departamento de Engenharia Agrícola, UFRPE, Recife, PE, Brasil. E-mail: mario.rolim@ufrpe.br

* Author for correspondence
} 


\section{Introduction}

Sugarcane cultivation plays a great economic role for Brazil, which holds the title of largest producer in the world. Cultivated areas are expanding and the harvested area for the sugar-alcohol activity is estimated at 9,004.5 thousand hectares, distributed in all Brazilian producing states. Currently, Pernambuco State is the second largest producer in the Northeast and the seventh in Brazil (CONAB, 2014).

Several factors may affect sugarcane production, being the plant-parasitic nematodes important pathogens of this crop. Among nematode species that parasitize this crop are Meloidogyne javanica, M. incognita, and Pratylenchus zeae. These species cause yield losses from 20 to $40 \%$ in the first sugarcane cutting of susceptible varieties, also reducing the longevity of sugarcane ratoon (DINARDO-MIRANDA, 2006). Damages vary according to the population level of nematode species, soil type, and cultivated variety (CHAVES et al., 2009).

On the other hand, composition and structure of nematode communities may undergo direct or indirect effect from soil properties (CARDOSO et al., 2012). Specifically, changes in soil organic matter content directly influence the habitat (BIEDERMAN; BOUTTON; WHISENANT, 2008), food chain (BERG; BENGTSSON, 2007) and reproduction (FARAHAT et al., 2012) of nematodes, which determines their spatial distribution (CADET; SPAULL, 2003).

In this context, the use of residues from sugarcane processing, such as filter cake and bagasse, has obtained satisfactory results in suppressing plant-parasitic nematode populations (STIRLING et al., 2003; CHIRCHIR et al., 2008). Thus, the addition of organic matter is one of the foundations to obtain a biological equilibrium in the soil, favoring the microfauna and, consequently, increasing the dominance of free-living nematodes (PAPATHEODOROU;
STAMOU, 2004; BERRY; CADET; SPAULL, 2005).

Nematode distribution in the field is aggregated (FERRIS; WILSON, 1987), which implies spatial dependence. Thus, in order to obtain information on the dynamics of nematode communities in the soil, adequate sampling and data analysis procedures are required (PINHEIRO et al., 2008). Geostatistical mapping allows visualizing the variability pattern of these organisms, constituting a useful tool for defining management strategies and recovery of infested areas (ORTIZ et al., 2010). However, studies on the spatial nematode distribution are incipient but relevant for the development of sampling plans aiming at the application in integrated pest management programs. Given the above, this study aimed to characterize the spatial nematofauna and soil organic matter distribution in a sugarcane field under fertigation with vinasse.

\section{Materials and Methods}

\section{Area characterization}

The study was carried out in an area intensely cultivated with sugarcane (variety RB863129), which had been managed under conventional planting for more than two decades. The area is located at the coordinates $7^{\circ} 33^{\prime} 38^{\prime \prime} \mathrm{S}$ and $35^{\circ} 00^{\prime} 09^{\prime}$ ' $\mathrm{W}$ and it is characterized by a sand-texture soil. Local climate, according to Köppen-Geiger Climate Classification (KOPPEN, 1948), is humid tropical type 'As', which is characterized by being warm and humid, with rainfall from autumn to winter (March to August), average annual temperatures varying around $24^{\circ} \mathrm{C}$, a very weak annual thermal amplitude (about $3{ }^{\circ} \mathrm{C}$ ) and isohyets ranging from $1,932.3$ to $975.6 \mathrm{~mm}$ per year.

\section{Soil sampling}

Soil samples were collected 50 days after sugarcane cutting (10 days after vinasse application) 
in a $60 \times 50-\mathrm{m}\left(3,000 \mathrm{~m}^{2}\right)$ square grid, with points spaced at $10 \mathrm{~m}$ intervals, totalizing 42 points, and collected at 0-0.2 $\mathrm{m}$ depth. Non-deformed samples were taken by a modified sampler with stainless steel cylinders $\mathrm{TORSOL}^{\circledR}$, with a diameter of 50 $\mathrm{mm}$, a height of $26.5 \mathrm{~mm}$ and a volume of $50 \mathrm{~cm}^{3}$.

\section{Nematological analyses}

Soil samples were homogenized and the nematodes extracted from $300-\mathrm{cm}^{3}$ soil aliquots by using the centrifugal flotation technique in a sucrose solution (JENKINS, 1964). Suspensions remained under refrigeration $\left(4-6{ }^{\circ} \mathrm{C}\right)$, and nematodes were counted on Peters'slides under an optical microscope. Nematodes were classified as plant-parasitics (ectoparasites and endoparasites) and free-living. Ectoparasite nematodes remain outside the host and penetrate only the stylet (e.g. Helicotylenchus). Sedentary endoparasite nematodes fully penetrate the roots, causing the formation of nourishing cells and becoming obese (e.g. Meloidogyne). Nonplant-parasitic nematodes were classified as freeliving nematodes. Identification was conducted at genus level for plant-parasitic nematodes and at family level for free-living nematodes, according to the keys of Mai et al. (1996) and Tarjan, Esser and Chang (1977). Among the plant-parasitic nematodes, the ectoparasites found were those from the genus Helicotylenchus, Xiphinema, Hemicycliophora, Trichodorus, and Criconemella; the found endoparasites belong to the genus Meloidogyne. Among the free-living nematodes, individuals of the families Dorylaimidae, Mononchidae, Rhabditidae, Cephalobidae, and Aphelenchidae were identified.

\section{Soil organic matter quantification}

Soil organic matter content was determined by the method described by EMBRAPA (2009), in which organic matter undergoes wet chemical oxidation with potassium dichromate in sulfuric acid. Unconsumed potassium dichromate is titrated with an ammoniacal ferrous sulfate solution and determined organic carbon content. Finally, soil organic matter content is determined by multiplying the resulting value by 1.724 .

\section{Data analysis}

Descriptive statistical analysis was carried out by means of measures of central tendency and dispersion and adherence to normal distribution according to the Kolmogorov-Smirnov test, at levels of 1 and 5\% significance. Discrepant data were eliminated based on the Hoaglin (1983) criterion, which considers as discrepant those data below the lower limit (L1) or above the upper limit $(\mathrm{Lu})$, respectively estimated by $\mathrm{Ll}=\mathrm{Q} 1-1.5 \mathrm{IQR}$ and $\mathrm{Lu}=\mathrm{Qu}+1.5 \mathrm{IQR}$, where $\mathrm{Q} 1$ and $\mathrm{Qu}$ are the lower and upper quartiles, respectively, and IQR is the interquartile range.

In order to classify the analyzed attribute variability, Warrick and Nielsen (1980) criteria were adopted: $\mathrm{CV}<12 \%$ (low), $12 \leq \mathrm{CV} \leq 62 \%$ (medium) and $\mathrm{CV}>62 \%$ (high). The degree of spatial dependence analysis was performed according to Cambardella et al. (1994), for whom the spatial dependence is considered as strong when semivariograms present a nugget effect to sill ratio smaller than or equal to $25 \%$, moderate for values between $25 \%$ and $75 \%$, and weak for values higher than $75 \%$.

For the geostatistical analysis, the software GEOEAS (Geostatistical Environmental Assessment Software) (ENGLUND, SPARKS, 1991) was used adopting the classical semivariance estimator, in which $\gamma$ is the semivariance value, estimated from the experimental data, and $\mathrm{N}(\mathrm{h})$ is the number of pair of observations $\mathrm{Z}\left(\mathrm{x}_{\mathrm{i}}\right)$ and $\mathrm{Z}\left(\mathrm{x}_{\mathrm{i}}+\mathrm{h}\right)$, separated by distance $h$ :

$$
\gamma(h)=\frac{1}{2 N(h)} \sum_{i=1}^{N(h)}[Z(x i)-Z(x i+h)]^{2}
$$


The theoretical semivariogram parameters were represented in graphs defined by means of range (a), sill (C) and nugget effect $\left(\mathrm{C}_{0}\right)$, adjusted in order to minimize the mean squared errors. Model adjustments were chosen considering the semivariogram parameters, the coefficient of determination $\left(\mathrm{R}^{2}\right)$ and auto-validation ('JackKnifing'). Each measured value was interpolated by the kriging method, successively eliminating the measured values, which were replaced by the estimates, then calculating the distribution of standard errors (OLIVER; WEBSTER, 2014).

With the adjustment of theoretical models and definition of semivariogram coefficients, the ordinary kriging was used to estimate values of attributes spatially distributed from adjacent values (OLIVER; WEBSTER, 2014). Surfer Software (GOLDEN SOFTWARE, 1995) was used to elaborate maps of spatial distribution of variables based on values estimated by kriging, previously carried out with the software GEO-EAS (ENGLUND; SPARKS, 1991).

\section{Results and Discussion}

Descriptive analysis for nematofauna and soil organic matter variables is described in Table 1. The Kolmogorov-Smirnov (KS) test at 1\% and 5\% probability indicated normality for all variables under study, which could also be observed in the joint analysis for values of means, medians, and kurtosis.

Table 1. Descriptive statistic for soil organic matter and plant-parasitic nematode in sugarcane field under fertigation with vinasse.

\begin{tabular}{ccccc}
\hline & Ectoparasites $^{\bullet}$ & Endoparasites $^{\bullet}$ & Free living & OM \\
\hline Mean & 512.47 & 179.92 & 715.41 & 2.79 \\
Median & 459.00 & 180.00 & 568.00 & 2.89 \\
Minimum & 0.00 & 0,00 & 168.00 & 1.71 \\
Maximum & 1386.00 & 404.00 & 1761.00 & 3.97 \\
Skewness & 0.61 & 0.25 & 1.10 & -0.12 \\
Kurtosis & -0.60 & -0.81 & 0.74 & -0.17 \\
CV(\%) & 71.85 & 61.36 & 58.08 & 19.48 \\
SD & 368.21 & 110.41 & 415.48 & 0.54 \\
KS & $*$ & $*$ & $*$ & $*$ \\
\hline
\end{tabular}

$\mathrm{CV}=$ coefficient of variation, $\mathrm{SD}=$ standard deviation, $\mathrm{KS}=$ Kolmogorov-Smirnov test, (*) normal distribution at 1 and $5 \%$ significance, $\mathrm{OM}=$ organic matter $(\%)$. $(\bullet)$ individuals per $300 \mathrm{~cm}^{3}$ soil.

Regarding data variability, ectoparasite nematodes $(\mathrm{CV}=71 \%)$ presented high variability and endoparasites $(\mathrm{CV}=61 \%)$, free-living $(\mathrm{CV}=$ $58 \%)$ and soil organic matter $(\mathrm{CV}=19 \%)$ presented a medium variation. According to Campos et al. (2009), coefficients of variation allow comparing values between different soil attributes and average values can be considered as the first indicators of the existence of data heterogeneity.

Spatiotemporal distribution of nematode communities varies according to biology, feeding habit and availability of host plants. In agricultural areas, their distribution is generally considered as aggregate (FERRIS; WILSON, 1987). However, sedentary endoparasite nematodes (e.g. Meloidogyne) deposit all their eggs at the same place, in a mass form, generating a highly aggregated spatial distribution pattern. On the other hand, ectoparasite nematodes (e.g. Helicotylenchus) deposit their eggs individually, resulting in a random distribution pattern (BENN; SCHOMAKER, 2006). Thus, that is the reason why the ectoparasite 
nematodes presented greater spatial variability than the sedentary endoparasite nematodes.

According to the experimental semivariogram parameters, all studied variables presented spatial dependence (Table 2 and Figure 1). The spherical model presented the best fit to the semivariograms of soil organic matter and endoparasite (genus Meloidogyne) and free-living (Dorylaimidae, Mononchidae, Rhabditidae, Cephalobidae, and Aphelenchidae) nematodes, considering the highest value of the coefficient of determination $\left(\mathrm{R}^{2}\right)$. The exponential model better described ectoparasite nematodes (Helicotylenchus, Xiphinema, Hemicycliophora, Trichodorus, and Criconemella). Range values obtained for nematodes and soil organic matter were 10 and $19 \mathrm{~m}$, respectively. According to Pinheiro et al. (2008), classical statistics can be applied from samples collected above these distances, i.e. the radius of spatial dependence and domain of geostatistics for these variables is in the values up to these respective distances.

Table 2. Experimental semivariogram parameters for soil nematode and organic matter.

\begin{tabular}{|c|c|c|c|c|c|c|c|c|}
\hline & \multicolumn{3}{|c|}{ Semivariogram parameters } & \multirow{2}{*}{$\mathrm{C}_{0} /\left(\mathrm{C}_{0}+\mathrm{C}_{1}\right)$} & \multirow[t]{2}{*}{ Model } & \multicolumn{2}{|c|}{ Auto-validation } & \multirow{2}{*}{$\mathrm{R}^{2}$} \\
\hline & $\mathrm{C}_{0}$ & $\mathrm{C}_{0}+\mathrm{C}_{1}$ & $a(m)$ & & & Mean & SD & \\
\hline Ecto & 98180.60 & 126361.20 & 10.26 & 0.78 & Exponential & 0.031 & 0.890 & 0.56 \\
\hline Endo & 8584.40 & 13168.80 & 16.71 & 0.65 & Spherical & 0.043 & 0.958 & 0.32 \\
\hline FL & 96606.60 & 173213.33 & 19.08 & 0.56 & Spherical & 0.029 & 0.910 & 0.85 \\
\hline $\mathrm{OM}$ & 0.09 & 0.065 & 18.07 & 0.58 & Spherical & 0.034 & 0.884 & 0.57 \\
\hline
\end{tabular}

$\mathrm{C}_{0}=$ nugget effect, $\mathrm{C}_{0}+\mathrm{C}_{1}=$ sill, a $(\mathrm{m})=$ range, $\mathrm{C}_{0} /\left(\mathrm{C}_{0}+\mathrm{C}_{1}\right)=$ indicator of the spatial structure degree. $\mathrm{C}_{0} / \mathrm{C}_{0}+\mathrm{C}_{1} \leq 0,25=$ strong spatial dependence; $0,25 \leq \mathrm{C}_{0} / \mathrm{C}_{0}+\mathrm{C}_{1} \leq 0,75=$ moderate spatial dependence; $0,75<\mathrm{C}_{0} / \mathrm{C}_{0}+\mathrm{C}_{1}<1,00=$ weak spatial dependence; $\mathrm{C}_{0} / \mathrm{C}_{0}+\mathrm{C}_{1}=1,00=$ no spatial dependence (pure nugget effect), Ecto $=$ ectoparasites, Endo $=$ endoparasites, $\mathrm{FL}=$ free living, $\mathrm{OM}$ $=$ organic matter, $\mathrm{SD}=$ standard deviation.

Experimental semivariogram parameters estimated for spherical and exponential models $\left(\mathrm{C}_{0}\right.$, $\mathrm{C}_{1}$, a) were endorsed by the Jack-Knifing test since mean values of reduced errors were close to 0 and standard deviation of reduced errors were close to 1 (Table 2).

According to the $\mathrm{C}_{0} / \mathrm{C}_{0}+\mathrm{C}$ ratio, a moderate spatial dependence was observed for endoparasite nematodes, free-living and soil organic matter, with $65 \%, 56 \%$, and $58 \%$, respectively. A low spatial dependence was observed for ectoparasite nematodes, which obtained $78 \%$ randomness of samples (Table 2). The low spatial dependence of variables may be a result of soil management in the study area, which is characterized by the excessive traffic of heavy machinery, burning and use of residues, such as vinasse.

When analyzing the kriging maps, no visual correspondence was observed between soil organic matter and endoparasite and ectoparasite nematodes (Figures 2a, 2b, and 2d). However, a visual correspondence was observed for free-living nematodes (Figures $3 \mathrm{c}$ and $3 \mathrm{~d}$ ). Therefore, the areas with a lower abundance of plant-parasitic nematode population (endoparasites and ectoparasites) presented higher soil organic matter content. In contrast, free-living nematodes behaved inversely. Pearson correlations presented in Table 3 can confirm this result. 
Figure 1. Experimental semivariograms of (a) ectoparasites, (b) endoparasites, (c) free living nematodes and (d) soil organic matter.
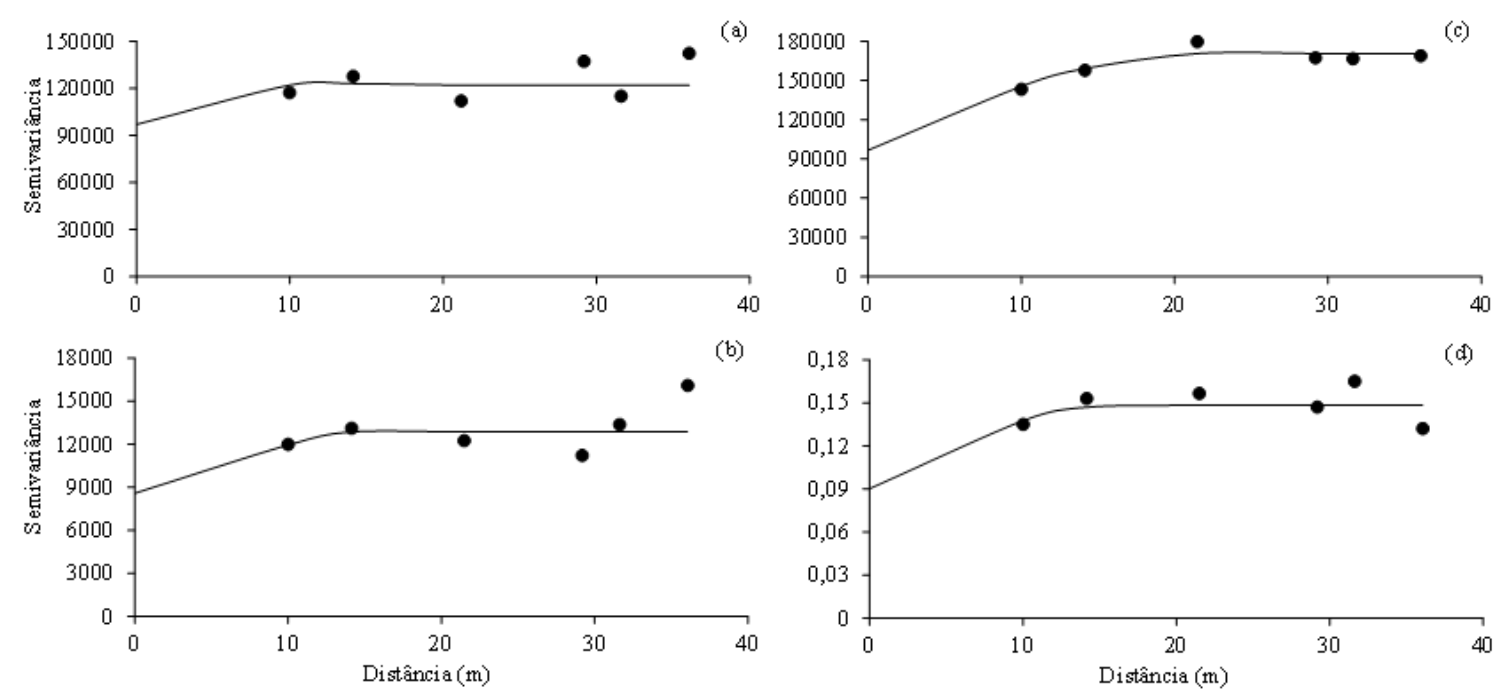

Table 3. Pearson correlation coefficient of soil nematode abundance and organic matter.

\begin{tabular}{cccc}
\hline \multirow{2}{*}{$\mathrm{OM}$} & Ectoparasites & Endoparasites & Free living \\
\cline { 2 - 4 } & $-0.675^{*}$ & $-0.721^{*}$ & $0.688^{* *}$ \\
\hline
\end{tabular}

$\mathrm{OM}=$ organic matter. $*$ Significant at $5 \%$ probability $; * *$ Significant at $1 \%$ de probability.

Vinasse application in the study area may have influenced the results described because it is a residue rich in organic matter, which provides energy (carbon) to edaphic microfauna, thus promoting biomass increasing and its activity (MENG et al., 2009). Vinasse also presents high levels of potassium and the presence of this ion in the soil can cause plant-parasitic nematode population reduction, as it interferes with the development of certain species of the genus Meloidogyne (CASTRO et al., 1990). This corroborates the study conducted by Pedrosa et al. (2005), who observed a reduction of juvenile hatching and a population density of $M$. incognita and $M$. javanica after vinasse application.

Therefore, the use of organic compounds from sugarcane processing, such as bagasse and filter cake, can suppress plant-parasitic nematodes (CHIRCHIR et al., 2008). However, soil biology can be altered according to quality and quantity of organic material added (STIRLING et al., 2003). In addition, this material may form organic substances, such as volatile fatty acids, which may present nematicidal action (NOVARETTI, 1983).

On the other hand, soil organic matter contents were positively correlated with free-living nematodes, probably due to favoring of microbial community (bacteria and fungi), which resulted in an increase in these nematode population (PAPATHEODOROU; ARGYROPOULOU; STAMOU, 2004; BERRY; CADET; SPAULL, 2005). Therefore, soil organic matter affects the spatial soil nematofauna distribution (CADET; SPAULL, 2003), with a significant effect on the mycophagous nematode communities (PENMOURATOV et al., 2010) and on the abundance of bacteriophage nematodes, when the organic material added presents high quality (e.g. rich in nutrients and low C:N ratio) (BERG; BENGTSSON, 2007). 
Figure 2. kriged maps representing the distribution and correlation of nematode and organic matter: (a) ectoparasites, (b) endoparasites, (c) free living and (d) soil organic matter (\%). A = nematode abundance in $300 \mathrm{~cm}^{3}$ soil.
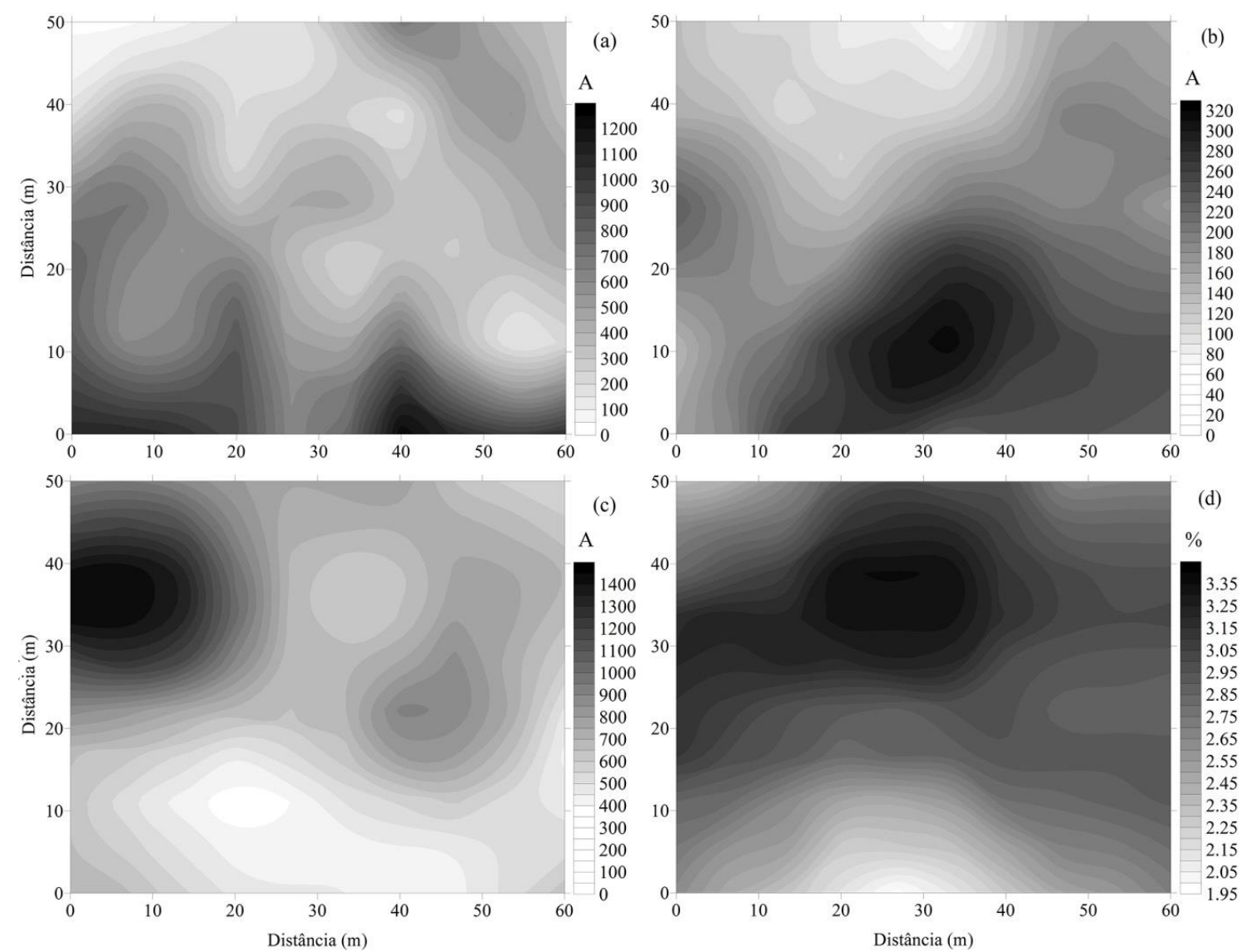

\section{Conclusions}

The mapping allowed observing similar spatial distribution patterns between free-living nematode communities and soil organic matter, indicating that organic compounds play an important role in the spatial distribution of these nematodes in the soil.

The highest soil organic matter contents were correlated with the lower abundance of plantparasitic nematodes, suggesting that organic compounds addition is an alternative for suppressing these nematodes.

\section{Acknowledgements}

The authors are grateful to the Coordination for the Improvement of Higher Education Personnel
(CAPES) and Foundation for Science and Technology of Pernambuco State (FACEPE) for the financial support.

\section{References}

BENN, T.; SCHOMAKER, C. H. Distribution patterns and sampling. In: PERRY, R. N.; MOENS, M. Plant nematology. Wallingford: CAB International, 2006. p. 302-326.

BERG, M. P.; BENGTSSON, J. Temporal and spatial variability in soil food web structure. Oikos, v. 116, n. 11, p. 1789-1804, 2007.

BERRY, S.; CADET, P.; SPAULL, V. W. Effect of certain cultural practices on nematode management in a smallscale farming system. Proceedings of South African Sugar Technologists, Durban, v. 79, p. 149-164, 2005. 
BIEDERMAN, L. A.; BOUTTON, T. W.; WHISENANT, S. G. Nematode community development early in ecological restoration: the role of organic amendments. Soil Biology and Biochemistry, Viterbo, v. 40, n. 9, p. 2366-2374, 2008.

CADET, P.; SPAULL, V. W. Effect of nematodes on sustainability of sugarcane production in South Africa. Field Crops Research, Amsterdam, v. 83, n. 1, p. 91-100, 2003.

CAMBARDELLA, C. A.; MOORMAN, T. B.; NOVAK, J. M.; PARKIN, T. B.; KARLEN, D. L.; TURCO, R. F.; KONOPKA, A. E. Field-scale variability of soil properties in central Iowa soils. Soil Science Society of America Journal, Madison, v. 58, n. 5, p. 1501-1511, 1994.

CAMPOS, M. C. C.; MARQUES JÚNIOR, J.; PEREIRA, G. T.; SOUZA, Z. M.; MONTANARI, R. Planejamento agrícola e implantação de sistema de cultivo de cana-deaçúcar com auxílio de técnicas geoestatísticas. Revista Brasileira de Engenharia Agrícola e Ambiental, Campina Grande, v. 13, n. 3, p. 297-304, 2009.

CARDOSO, M. O.; PEDROSA, E. M. R.; ROLIM, M. M.; SILVA, E. F. F.; BARROS, P. A. Effects of soil mechanical resistance on nematode community structure under conventional sugarcane and remaining of Atlantic Forest. Environmental, Monitoring and Assessment, Basel, v. 184, n. 6, p. 3529-3544, 2012.

CASTRO, C. E.; BELSER, N. O.; MCKINNEY, H. E.; THOMASON, I. J. Strong repellency of the root knot nematode, Meloidogyne incognita by specific inorganic ions. Journal of Chemical Ecology, Bethesda, v. 16, n. 4, p. 1199-1205, 1990.

CHAVES, A.; MARANHÃO, S. R. V. L.; PEDROSA, E. M. R.; GUIMARÃES, L. M. P.; OLIVEIRA, M. K. R. S. Incidência de Meloidogyne ssp. e Pratylenchus zeae em cana-de-açúcar no estado de Pernambuco, Brasil. Nematologia Brasileira, Piracicaba, v. 33, n. 4, p. 278280, 2009.

CHIRCHIR, A. K.; KIMENJU J. W.; OLUBAYO F. M.; MUTUA, G. K. Abundance and distribution of plant parasitic nematodes associated with sugarcane in western Kenya. Asian Journal of Plant Pathology, Deira, v. 2, n. 1, p. 48-53, 2008.

COMPANHIA NACIONAL DE ABASTECIMENTO - CONAB. Acompanhamento de safra brasileira: canade-açúcar, $3^{\circ}$ levantamento, dezembro/2014. Brasília: Conab, 2014. Disponível em: <http://www.conab.gov. $\mathrm{br} /$ OlalaCMS/uploads/arquivos/14 $12 \quad 19 \quad 09 \quad 02 \quad 49$ boletim cana portugues - 3o lev - $2014-\overline{1} 5 . \overline{p d f}>$. Acesso em: 27 fev. 2015.
DINARDO-MIRANDA, L. L. Manejo de nematoides e pragas de solo em cana-de-açúcar. In: CAMPOS, A.P.; VALE, D. W.; ARAÚJO, E. S.; CORRADI, M. M.; YAMAUTI, M. S.; FERNANDES, O. A.; FREITAS, S. Manejo integrado de pragas. Jaboticabal: FUNEP, 2006. v. 1, p. $59-80$.

EMPRESA BRASILEIRA DE PESQUISA AGROPECUÁRIA - EMBRAPA. Manual de análises químicas de solos, plantas e fertilizantes. Brasília, DF: Embrapa Informação Tecnológica, 2009. 627 p.

ENGLUND, E.; SPARKS, A. Geo-EAS - geostatistical enviromental assessment software. Las Vegas, U.S: Enviromental Protency Agency, 1991.

FARAHAT, A. A.; ALSAYED, A. A.; EL-BELTAGY, H. S.; MAHFOUD, N. A. Impact of organic and inorganic fertilizers on nematode reproduction and biochemical alterations on tomato. Notulae Scientia Biologicae, ClujNapoca, v. 4, n. 1, p. 48-55, 2012.

FERRIS, H.; WILSON, L. T. Concepts and principles of population dynamics. In: VEECH, J. A.; DICKSON, D. W. Vistas on nematology. Society of nematologists. Hyattsville: MD, 1987. p. 372-376.

GOLDEN SOFTWARE. Surfer for Windows: surface mapping system. Versão 6.01. Golden, 1995.

HOAGLIN, D. C.; MOSTELLER, F.; TUKEY, J. W. Understanding robust and exploratory data analysis. New York: J. Wiley, 1983. 447 p.

JENKINS, W. R. A rapid centrifugal-flotation technique for separating nematodes from soil. Plant Disease Reporter, New Brunswick, v. 48, n. 9, p. 692, 1964.

KOPPEN, W. Climatología. Ciudad de México: Fondo de cultura Económica, 1948. 278 p.

MAI, W. F.; MULLIN, P. G.; LYON, H. H.; LOEFFLE, K. Plant-parasitic nematodes: a pictorial key to genera. 5. ed. Ithaca: Cornell Universiy Press, 1996. 277 p.

MENG, Y.; TANG Q.; LIU Z.; CHEN G.; WANG Y.; TAN Y. Effects of filter mud and vinasse from sugar factory on quantity of soil microorganism in sugarcane field. Guangxi Agricultural Sciences, Nanning, v. 40, n. 10, p. 1323-1330, 2009.

NOVARETTI, W. R. T. Nematoides parasitos da canade-açúcar e seu controle. Jaú: Copersucar, 1983. 6 p.

OLIVER, M. A.; WEBSTER, R. A tutorial guide to geostatistics: computing and modelling variograms and kriging. Catena, Gieben, v. 113, p. 56-69, 2014. 
ORTIZ, B. V.; SULLIVAN, D. G.; PERRY, C.; LU, P.; KEMERAIT, R.; DAVIS R. F. Geostatistical modeling of the spatial variability and risk areas of southern rootknot nematodes in relation to soil properties. Geoderma, Amsterdam, v. 156, n. 3, p. 243-252, 2010.

PAPATHEODOROU, E. M.; ARGYROPOULOU, M. D.; STAMOU, G. P. The effects of large and small-scale differences in soil temperature and moisture on bacterial functional diversity and the community of bacterivorous nematodes. Applied Soil Ecology, Amsterdam, v. 25, n. 1, p. 37-49, 2004.

PEDROSA, E. M. R.; AlBUQUeRQUE, P. H. S.; CUNHA, A. C.; ROLIM, M. M. Supressividade de nematoides em cana-de-açúcar por adição de vinhaça ao solo. Revista Brasileira de Engenharia Agrícola e Ambiental, Campina Grande, v. 9, p. 197-201, 2005. Suplemento.

PEN-MOURATOV, S.; HU, C.; HINDIN, E.; STEINBERGER, Y. Effect of sand-dune slope orientation on soil free-living nematode abundance and diversity. Helminthologia, Košice, v. 47, n. 3, p.179-188, 2010.
PINHEIRO, J. B; POZZA, E. A.; POZZA, A. A. A.; MOREIRA, A. S.; ALVES, M. C.; CAMPOS, V. P. Influência da nutrição mineral na distribuição espacial do nematóide de cisto da soja. Nematologia Brasileira, Piracicaba, v. 32, n. 4, p. 270-279, 2008.

STIRLING, G. R.; WILSON, E. J.; STIRLING, A. M.; PANKHURST, C. E.; MOODY, P. W.; BELL, M. J. Organic amendments enhance biological suppression of plant-parasitic nematodes in sugarcane soils. In: AUSTRALIAN SOCIETY OF SUGARCANE TECHNOLOGISTS, 25., 2003. Proceedings... Queensland: Conference of the Australian Society of Sugar Cane Technologists held at Townsville, 2003. p. $1-11$.

TARJAN, A. C.; ESSER, R. P.; CHANG, S. L. An illustrated key to nematodes found in freshwater. Journal of Water Pollution Control Federation, Washington, v. 49, n. 11, p. 2318-2337, 1977.

WARRICK, A. W.; NIELSEN, D. R. Spatial variability of same physical properties of the soil. In: HILL, D. Aplications of soil physics. New York: Academic Press, 1980. p. 319-344. 
